\title{
Kepemimpinan dan Tingkah Laku Kewiraswastaan dalam Industri Skala Kecil dan Menengah (Kasus Industri Sepatu Skala Kecil dan Menengah di Desa Ciomas dan Desa Pagelaran, Kecamatan Ciomas, Kabupaten Bogor, Propinsi fawa Barat)
}

\author{
Isnanik Dian Andriany ${ }^{1}$, Said Rusli ${ }^{2}$
}

\section{Ringkasan}

Tulisan ini merupakan hasil penelitian yang bertujuan untuk menelaah kepemimpinan dan tingkah laku kewiraswastaan pengusaha pada industri kecil dan menengah, menganalisis hubungan kepemimpinan terhadap kinerja pekerja serta menganalisis hubungan kinerja pekerja dan tingkah laku kewiraswastaan pengusaha terhadap perkembangan usaha dan produktivitas. Adapun pendekatan yang digunakan yaitu pendekatan kuantitatif (metode survei) dan pendekatan kualitatif. Hasil penelitian menunjukkan adanya perbedaan antara industri kecil dan industri menengah. Perbedaan yang muncul seperti dalam penanganan terhadap pekerja, gaya kepemimpinan yang diterapkan dan tingkat tingkah laku kewiraswastaan. Tingkat tingkah laku kewiraswastaan pengusaha industri menengah tergolong lebih tinggi dibandingkan dengan pengusaha industri kecil baik pada tingkat pemikiran maupun pada tingkat tindakan. Pengusaha industri menengah lebih mampu mewujudkan tingkah laku kewiraswastaan pada tingkat pemikiran menjadi tindakan nyata dalam pengembangan usaha. Pada kedua industri terdapat hubungan yang nyata antara kinerja pekerja dan kepemimpinan. Selain itu, terdapat pula hubungan antara kinerja pekerja dan tingkah laku kewiraswastaan terhadap pengembangan usaha industri yang bersangkutan. Dengan tingkat kinerja pekerja dan tingkah laku kewiraswastaan pengusaha yang lebih tinggi (pada tingkat pemikiran dan tingkat tindakan), usaha industri menengah mengalami perkembangan usaha yang lebih cepat dan mempunyai produktivitas yang lebih tinggi dibandingkan dengan usaha industri kecil.

Katakunci: kepemimpinan, gaya kepemimpinan, tingkah laku kewiraswastaan, kinerja pekerja dan produktivitas

\section{Pendahuluan}

Sektor industri kecil dan menengah merupakan penyangga ekonomi Indonesia yang tidak boleh dianggap remeh. Hal ini terbukti, ketika krisis moneter yang berlanjut dengan krisis ekonomi melanda Indonesia pada tahun 1998, industri kecil dan menengah adalah sektor usaha yang mampu bertahan di tengah terpaan krisis tersebut. Dampak yang dirasakan terhadap eksistensi industri kecil dan menengah dari krisis ekonomi adalah tidak separah yang dirasakan

\footnotetext{
${ }^{1}$ Lulusan Program Studi Komunikasi dan Pengembangan Masyarakat. IPB, Bogor

2 Staf pengajar Fakultas Ekologi Manusia dan merupakan pembimbing skripsi penulis pertama
} 
oleh industri besar. Pada tahun 1999, roda usaha industri kecil dan menengah mulai bergerak lagi yang ditandai oleh bertambahnya usaha industri kecil dan menengah. Terdapat kenaikan sebesar 14.54 persen dibandingkan dengan tahun 1998 yaitu dari 2196899 unit usaha menjadi 2516275 unit usaha, walaupun kenaikan ini belum dapat melebihi angka pada tahun 1996 yaitu sebanyak 2867 241 unit usaha. Sementara, industri besar pada tahun 1999 menunjukkan penurunan sebesar 1.41 persen dibandingkan tahun 1998, dimana jumlah unit usaha sebesar 22286 unit usaha menjadi 22070 unit usaha (BPS, 2000).

Dengan semakin berkembangnya dunia usaha di Indonesia, dibutuhkan adanya perubahan pada pengelolaan industri kecil dan menengah agar industri tersebut mampu mengembangkan usaha dan meningkatkan produktivitasnya. Salah satu faktor yang dapat memberikan perubahan adalah melalui kepemimpinan yang terdapat dalam usaha tersebut. Kepemimpinan memegang peranan yang cukup penting karena perkembangan suatu usaha bergantung pada keberadaan kepemimpinan. Semakin efektif kepemimpinan dalam suatu usaha maka perkembangan usaha tersebut dapat semakin maju. Kepemimpinan berpengaruh dalam menumbuhkan kinerja para pekerja. Selain faktor kepemimpinan, perkembangan industri kecil dan menengah yang berkelanjutan tidak terlepas dari tingkah laku kewiraswastaan para pengelolanya. Banyak industri kecil dan menengah yang mungkin kurang berkembang oleh karena tingkah laku kewiraswastaan para pengelolanya kurang kondusif terhadap berkembangnya usaha yang bersangkutan.

Penelitian ini betujuan untuk menelaah kepemimpinan dan tingkah laku kewiraswastaan pengusaha pada industri sepatu skala kecil dan menengah, menganalisis hubungan kepemimpinan dalam industri kecil dan menengah terhadap kinerja pekerja serta menganalisis hubungan kinerja pekerja dan tingkah laku kewiraswastaan pengusaha terhadap perkembangan usaha dan produktivitas industri kecil dan industri menengah. Metode yang digunakan merupakan perpaduan dua pendekatan penelitian yaitu pendekatan kuantitatif (metode survei) dan pendekatan kualitatif. Hasil dari penelitian ini diharapkan dapat menambah literatur mengenai kepemimpinan, kewiraswastaan dan juga dapat bermanfaat untuk mendukung upaya-paya pengembangan industri kecil dan menengah.

\section{Landasan Teori dan Kerangka Analisis}

\subsection{Landasan Teori}

Untuk membangun kerangka analisis didasarkan pada sejumlah kepustakaan. Kepustakaan yang dimaksud adalah tentang penggolongan industri, kepemimpinan, tingkah laku kewiraswastaan, kinerja dan produktivitas. Definisi mengenai jenis industri didasarkan pada Badan Pusat Statistik yang membagi industri kecil menjadi 4 skala yaitu industri kerajinan rumah tangga, industri kecil, industri menengah dan industri besar. Industri kecil adalah 
usaha industri yang mempunyai tenaga kerja 5 - 19 orang. Sedangkan industri menengah adalah usaha industri yang mempunyai tenaga kerja 20 - 99 orang.

Konsep kepemimpinan yang digunakan merujuk pada Nawawi (2003), Soekanto (1990) dan juga Kottler (1997). Kepemimpinan didefinisikan sebagai suatu tindakan atau kegiatan yang ditujukan untuk mempengaruhi atau mengendalikan orang-orang dalam berperilaku agar tercipta kerjasama dalam rangka mencapai tujuan yang telah ditetapkan. Prasyarat kepemimpinan adalah sifat-sifat pribadi yang mempengaruhi keberadaan seseorang sebagai pemimpin baik yang merupakan sifat bawaan maupun sifat yang diperoleh atau dikembangkan melalui proses sosialisasi. Prasyarat kepemimpinan dilihat berdasarkan latar belakang pendidikan formal, pendidikan dari orang tua (informal), pengalaman kepemimpinan, dan kemampuan berkomunikasi. Sedangkan gaya kepemimpinan cara-cara dalam memimpin bawahan atau pekerja dan memecahkan masalah yang dihadapi dalam perusahaan.

Konsep tingkah laku kewiraswastaan yang digunakan dalam penelitian ini diadaptasi dari konsep yang dikemukakan oleh Gerschenkron (1966) dan Aziz (1978). Wiraswasta adalah orang yang mengambil keputusan ekonomi atau orang yang bekerja untuk mendapatkan keuntungan dengan menghasilkan barang atau jasa. Sedangkan tingkah laku kewiraswastaan adalah tingkah laku yang dicirikan oleh unsur-unsur kewiraswastaan yaitu inovasi, pembinaan modal, keberanian mengambil resiko dan menatalaksana. Tingkah laku kewiraswastaan ini dibedakan pada dua tingkatan yaitu tingkat pemikiran dan pada tingkat tindakan nyata.

Kinerja pekerja didasarkan pada pendapat Robbin (1996) yang dikutip oleh Novrizar (2002), sedangkan produktivitas didasarkan pada pendapat Simanjuntak (1983). Kinerja pekerja adalah pelaksaaan fungsi-fungi yang diharapkan dari seorang pekerja, menunjukkan aktivitas seorang pekerja dalam melaksanakan tugas dan berusaha mencapai tujuan yang telah ditetapkan. Kinerja ini diukur berdasarkan kriteria kedisiplinan, ketepatan dan ketelitian dalam menyelesaikan tugas serta produktivitas pekerja. Produktivitas adalah perbandingan antara masukan (input) dan keluaran (output).

\subsection{Kerangka Analisis}

Untuk menunjukkan hubungan kepemimpinan dan tingkah laku kewiraswastaan pengusaha serta pengaruhnya terhadap perkembangan industri kecil dan menengah dapat dilihat melalui bagan kerangka pemikiran pada Gambar 1. 


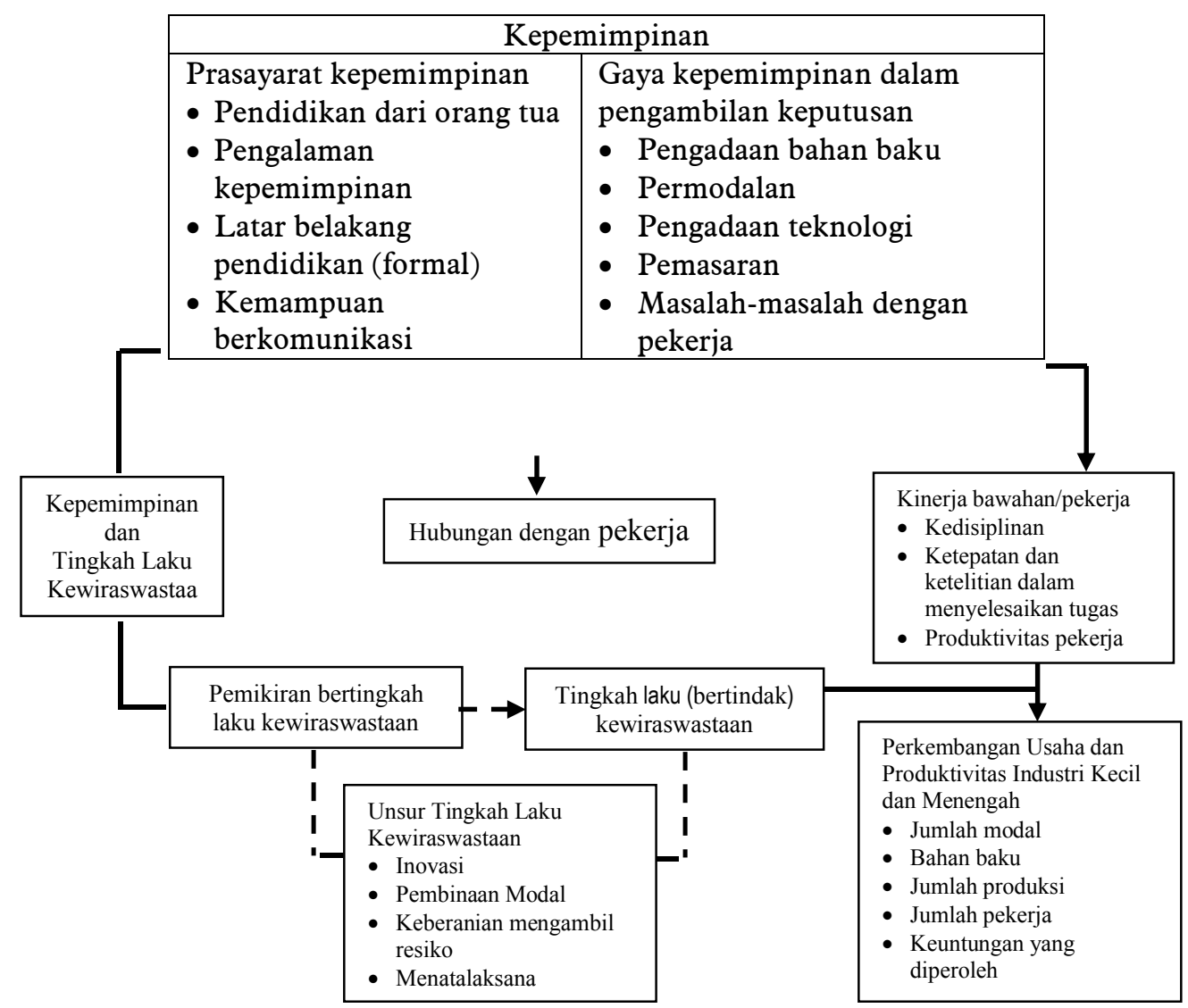

Gambar 1. Kerangka pemikiran

Dalam penelitian ini, aspek kepemimpinan yang ditelaah adalah prasyarat kepemimpinan, gaya kepemimpinan dan hubungan antara pemimpin dan pekerja. Prasyarat kepemimpinan meliputi latar belakang pendidikan (formal), pengalaman kepemimpinan, pendidikan dari orang tua (informal), dan kemampuan berkomunikasi. Sedangkan gaya kepemimpinan dilihat dari perilaku dasar pengambilan keputusan bidang pengadaan bahan baku, permodalan, pengadaan teknologi, pemasaran dan penanganan terhadap masalah-masalah pekerja. Hal ini dengan pertimbangan bahwa kepemimpinan yang ditelaah adalah kepemimpinan organisasi usaha industri. Prasyarat kepemimpinan dan gaya kepemimpinan dalam perilaku dasar pengambilan keputusan yang diterapkan akan menentukan hubungan antara pemimpin dan pekerja yang dapat berpengaruh terhadap kinerja pekerja. Hubungan pemimpin dan pekerja juga digunakan sebagai indikator kepemimpinan yang terdiri dari penentuan upah, penanganan kesalahan pekerja, penetapan peraturan, kerjasama, dan penghargaan terhadap pekerja. Kinerja pekerja ditelaah pada indikator kinerja yang terdiri dari kedislipinan pekerja, ketepatan dan ketelitian dalam meyelesaikan tugas, serta produktivitas pekerja. 
Tingkah laku kewiraswastaan pengusaha dikaji pada tingkat pemikiran dan tingkat tindakan (senyatanya). Tingkah laku kewiraswastaan pada tingkat pemikiran merupakan keinginan dari pengusaha untuk melakukan unsur-unsur kewiraswastaan. Sedangkan pada tingkat senyatanya, tingkah laku kewiraswastaan merupakan tindakan untuk melakukan unsur-unsur kewiraswastaan. Adapun unsur kewiraswastaan yang ditelaah mencakup unsur inovasi, pembinaan modal, keberanian mengambil resiko dan menatalaksana. Kepemimpinan dan tingkah laku kewiraswastaan berpengaruh terhadap produktivitas industri yang bersangkutan. Dengan produktivitas yang meningkat akan berdampak pada keberlangsungan dan perkembangan usaha industri kecil dan menengah itu sendiri.

Produktivitas dibedakan antara produktivitas pekerja dan produktivitas usaha (perusahaan) industri. Produktivitas pekerja diukur sebagai bagian dari kinerja pekerja. Produktivitas usaha (perusahaan) tidak diukur secara langsung. Produktivitas perusahaan diukur berdasarkan penilaian pengusaha terhadap variabel-variabel yang berpengaruh atau yang dapat mengukur produktivitas perusahaan. Variabel tersebut termasuk dalam kategori variabel masukan dan variabel keluaran. Variabel masukan terdiri dari jumlah modal, jumlah bahan baku, dan jumlah pekerja. Sedangkan variabel keluaran yaitu jumlah produksi dan jumlah keuntungan. Variabel-variabel ini juga merupakan indikator variabel yang menentukan perkembangan usaha. Perubahan produktivitas dilihat sebagai bagian dari perubahan dalam perkembangan usaha (perusahaan). Untuk kepentingan penelitian ini diasumsikan bahwa perubahan dalam jumlah keuntungan merupakan indikator dari perubahan dalam produktivitas industri sepatu skala kecil dan menengah.

\section{Kepemimpinan Pengusaha pada Industri Sepatu Skala Kecil dan Menengah}

Kepemimpinan kedua pengusaha baik pada aspek prasyarat kepemimpinan, gaya kepemimpinan dalam perilaku dasar pengambilan keputusan dan hubungan antara pemimpin dan pekerja tampak tidak terlepas dari proses sosialisasi yang diterima dari orang tua (dalam keluarga) dan pengalamanpengalaman kepemimpinan yang diperoleh selama bersekolah ataupun di lingkungan masyarakat. Kedua pengusaha mempunyai kemampuan menjalankan kepemimpinan yang efektif di kalangan pekerja, meskipun terdapat perbedaan-perbedaan. Perbedaan kepemimpinan antara industri kecil dan menengah berdasarkan indikator kepemimpinan dapat dilihat pada Tabel 1. 
Tabel 1 Perbandingan kepemimpinan dalam industri kecil dan menengah berdasarkan pada indikator kepemimpinan

\begin{tabular}{lcccc}
\hline \multirow{2}{*}{$\begin{array}{c}\text { Indikator } \\
\text { Kepemimpinan }\end{array}$} & $\begin{array}{c}\text { Rata- } \\
\text { rata } \\
\text { skor }\end{array}$ & $\begin{array}{c}\text { Persentase rata-rata } \\
\text { skor dari rata-rata } \\
\text { skor maksimal }\end{array}$ & $\begin{array}{c}\text { Rata- } \\
\text { rata } \\
\text { skor }\end{array}$ & $\begin{array}{c}\text { Persentase rata-rata } \\
\text { skor dari rata-rata } \\
\text { skor maksimal }\end{array}$ \\
\hline Penentuan upah & 6.8 & 68 & 7 & 70 \\
\hline $\begin{array}{l}\text { Penanganan } \\
\text { terhadap kesalahan } \\
\text { pekerja }\end{array}$ & 9.4 & 63 & 12 & 80 \\
\hline $\begin{array}{l}\text { Penetapan } \\
\text { peraturan }\end{array}$ & 3.5 & 70 & 3.5 & 70 \\
\hline Kerjasama & 8 & 80 & 7.5 & 75 \\
\hline $\begin{array}{l}\text { Penghargaan } \\
\text { terhadap pekerja }\end{array}$ & 7.7 & 77 & 7 & 70 \\
\hline Semua indikator & 35.4 & 70.8 & 37 & 74 \\
\hline
\end{tabular}

Tabel 1 menunjukkan bahwa terdapat perbedaan antara kepemimpinan dalam industri kecil dan kepemimpinan dalam industri menengah terutama terlihat pada indikator-indikator kepemimpinan. Apabila dilihat dari semua indikator kepemimpinan, industri menengah memiliki skor yang lebih tinggi jika dibandingkan dengan industri kecil. Industri menengah memiliki skor ratarata 37 atau 74 persen, sedangkan industri kecil memiliki skor rata-rata sebesar 35.4 atau 70.8 persen.

Perbedaan yang paling terlihat dari kepemimpinan ini adalah pada indikator penanganan terhadap kesalahan pekerja. Persentase industri menengah untuk indikator penanganan terhadap kesalahan pekerja adalah 80 persen, sedangkan industri kecil 63 persen. Hal ini karena memang terdapat perbedaan dalam penanganan kesalahan pekerja pada dua industri tersebut. Pada industri kecil, apabila terdapat pekerja yang berbuat kesalahan, mereka hanya mendapat teguran dari pemimpin dan tidak diberikan sanksi lainnya. Dalam hubungan ini seorang responden pekerja pada industri kecil mengungkapkan sebagai berikut:

"Kalau ada pekerja yang salah, paling cuma ditegur sama pemimpin, tidak diberi hukuman. Paling dinasehati saja supaya lebih hati-hati kalo membuat sepatu”.

Sedangkan pada industri menengah, apabila pekerja berbuat kesalahan terutama dalam produksi sepatu, selain ditegur oleh pemimpin juga diberikan sanksi untuk memperbaiki kesalahnnya tersebut.

Selain itu, perbedaan kepemimpinan dalam industri kecil dan menengah juga terlihat dari gaya kepemimpinan dalam perilaku dasar pengambilan keputusan yang diterapkan pada kedua industri tersebut. Pada industri kecil, gaya 
kepemimpinan yang diterapkan adalah gaya instruksi dan konsultatif. Sedangkan pada industri menengah hanya gaya instruksi. Gaya konsultatif memberi peluang kepada pekerja untuk terlibat dalam pengambilan keputusan pada bidang-bidang tertentu. Pada industri menengah, gaya kepemimpinan yang diterapkan hanya gaya instruksi dimana gaya ini memberikan batasan bagi para pekerja, pekerja tidak dilibatkan dalam proses pengambilan keputusan.

Sehubungan dengan perbedaan kepemimpinan dalam industri kecil dan menengah perlu juga dikemukakan bahwa kepemimpinan terkait dengan tiga faktor (Kartodirdjo, 1984), yaitu:

1. Kepribadian (sifat-sifat) pemimpin

2. Sifat (karakteristik) golongan atau orang-orang yang dipimpin

3. Situasi atau kejadian dimana kepemimpinan tersebut berlangsung

Kepribadian atau sifat-sifat pemimpin pengusaha industri kecil dan menengah masing-masing selain dari sifat-sifat "bawaan" juga dari hasil proses sosialisasi. Karakteristik golongan merupakan karakteristik pekerja pada masing-masing usaha industri. Sedangkan situasi atau kejadian adalah lingkungan perusahaan yang mengkondisikan sebagai kepemimpinan organisasi dengan tugas-tugas pekerja dalam proses produksi.

Efektivitas kepemimpinan diwujudkan dalam meningkatkan kinerja pekerja untuk mencapai tujuan perusahaan. Salah satu prinsip kepemimpinan yang efektif adalah kemampuan memenuhi (pemuasan) kebutuhan bersama. Tampak bahwa kepemimpinan dalam industri menengah lebih mampu memenuhi kebutuhan pekerja dibandingkan dengan pada industri kecil, selain mampu memenuhi kebutuhan masing-masing pemimpin.

\section{Tingkah Laku Kewiraswastaan Pengusaha Sepatu Industri Kecil dan Menengah}

Sebagaimana yang telah dikemukakan pada kerangka analisis, unsur-unsur tingkah laku kewiraswastaan yang dikaji dibatasi pada tingkah laku (1) inovasi, (2) pembinaaan modal, (3) keinginan mengambil resiko, dan (4) menatalaksana.

Tingkah laku inovasi pada tingkat pemikiran ditunjukkan dengan keinginan untuk menghasilkan produk baru, keinginan untuk menggunakan alat baru dan menemukan cara (teknik) baru dalam proses produksi, serta keinginan untuk mencari cara baru dalam pemasaran produk. Tingkah laku inovasi pada tingkat tindakan ditunjukkan dengan produk baru yang dihasilkan, penggunaan alat baru dan cara-cara baru dalam proses produksi serta cara baru untuk memasarkan produk.

Tingkah laku pembinaan modal pada tingkat pemikiran ditunjukkan oleh keinginan untuk memperoleh pinjaman modal dari bank atau pihak lain dan keinginannya untuk menyisihkan sebagian keuntungan. Pada tingkat tindakan 
ditunjukkan oleh pinjaman modal yang diterima pengusaha industri kecil dan menengah dari bank atau dari pihak lain dan kegiatan menyisihkan sebagian keuntungan yang diperoleh.

Pada tingkat pemikiran, unsur keberanian mengambil resiko diukur berdasarkan keinginan (kesediaan) untuk menanggung resiko terhadap keputusan yang akan diambil untuk pengembangan usaha industri pada aspek pengambilan kredit (pinjaman modal) dan pembuatan produk-produk baru. Pada tingkat tindakan, diukur pada dilakukannya pengambilan kredit dan pembuatan produk-produk baru untuk pengembangan usaha dengan kesediaan menerima resiko yang telah diperhitungkan. Tingkah laku menatalaksana pada tingkat pemikiran ditunjukkan oleh keinginan perencanaan produksi dan keinginan untuk membuat pembukuan, sedangkan pada tingkat senyatanya ditunjukkan dari perencanaan-perencanaan yang dibuat oleh industri yang bersangkutan dan pembukuan yang dimiliki.

Tabel 2 memperlihatkan adanya perbedaan tingkah laku kewiraswastaan antara pengusaha industri kecil dan menengah baik pada tingkat pemikiran maupun pada tingkat tindakan. Perbedaan jelas terlihat pada unsur inovasi, pembinaan modal, dan keberanian mengambil resiko.

Pada tingkat pemikiran, unsur inovasi antara industri kecil dan menengah tidak menunjukkan perbedaan, keduanya memiliki skor yang sama yaitu 18 atau 90 persen, akan tetapi pada tingkat tindakan industri kecil memiliki skor 12 atau 60 persen sedangkan industri menengah memiliki skor 15 atau 75 persen. Untuk unsur pembinaan modal, pada kedua tingkatan industri kecil memiliki skor masing masing sebesar 9 atau 60 persen, sedangkan pada indistri menengah memiliki skor masing-masing adalah 14 atau 93.3 persen. Pada tingkat pemikiran, unsur keberanian mengambil resiko industri kecil memperoleh skor 11 atau 73.3 persen dan industri menengah memperoleh skor 15 atau 100 persen, sedangkan pada tingkat tindakan, industri kecil memperoleh skor 6 atau 60 persen dan industri menengah memiliki skor 15 atau 100 persen.

Secara keseluruhan (total semua unsur), skor tingkah laku kewiraswastaan pengusaha industri menengah pada tingkat pemikiran lebih tinggi dibandingkan dengan pengusaha industri kecil (57 atau 95 persen berbanding 48 atau 80 persen). Bahkan pada tingkat tindakan atau senyatanya, perbedaan tingkah laku kewiraswastaan lebih besar (54 atau 90 persen berbanding 38 atau 63.3 persen). Kesenjangan antara tingkah laku kewiraswastaan pengusaha industri kecil pada tingkat pemikiran dan tingkat tindakan sebesar 16.7 persen. Nilai ini lebih besar jika dibandingkan dengan kesenjangan tingkah laku kewiraswastaan pengusaha industri menengah yang hanya 5 persen. Keadaan ini menunjukkan bahwa pengusaha industri menengah lebih mampu mewujudkan tingkah laku kewiraswastaan yang ada pada tingkat pemikiran ke dalam bentuk tindakan ataupun bentuk nyata dalam mengembangkan industri sepatu. 
Perbedaan tingkah laku kewiraswastaan pada pengusaha industri sepatu skala kecil dan menengah tampak disebabkan oleh adanya beberapa faktor, antara lain modal yang dimiliki, pengetahuan, dan pengalaman. Keinginan untuk maju dan kemampuan mewujudkannya lebih besar pada pengusaha industri menengah. Hal ini antara lain terkait dengan proses sosialisasi yang dialami masing-masing pengusaha.

Tabel 2 Perbandingan tingkah laku kewiraswastaan dalam industri kecil dan menengah

\begin{tabular}{|c|c|c|c|c|c|c|c|c|c|c|}
\hline \multirow{3}{*}{$\begin{array}{l}\text { Unsur Tingkah } \\
\text { laku } \\
\text { Kewiraswastaan }\end{array}$} & \multicolumn{5}{|c|}{ Industri kecil } & \multicolumn{5}{|c|}{ Industri menengah } \\
\hline & \multicolumn{2}{|c|}{ Pemikiran } & \multicolumn{2}{|c|}{ Tindakan } & \multirow{2}{*}{$\begin{array}{c}\text { Selisih } \\
(\%)\end{array}$} & \multicolumn{2}{|c|}{ Pemikiran } & \multicolumn{2}{|c|}{ Tindakan } & \multirow{2}{*}{$\begin{array}{c}\text { Selisih } \\
(\%)\end{array}$} \\
\hline & Skor & $\%$ & Skor & $\%$ & & Skor & $\%$ & Skor & $\%$ & \\
\hline Inovasi & 18 & 90 & 12 & 60 & 30 & 18 & 90 & 15 & 75 & 15 \\
\hline $\begin{array}{l}\text { Pembinaan } \\
\text { modal }\end{array}$ & 9 & 60 & 9 & 60 & 0 & 14 & 93.3 & 14 & 93.3 & 0 \\
\hline $\begin{array}{l}\text { Keberanian } \\
\text { mengambil } \\
\text { resiko }\end{array}$ & 11 & 73.3 & 9 & 60 & 13.3 & 15 & 100 & 15 & 100 & 0 \\
\hline Menatalaksana & 10 & 100 & 8 & 80 & 20 & 10 & 100 & 10 & 100 & 0 \\
\hline Semua Unsur & 48 & 80 & 38 & 63.3 & 16.7 & 57 & 95 & 54 & 90 & 5 \\
\hline
\end{tabular}

\section{Kinerja Pekerja dan Hubungannya dengan Kepemimpinan dalam Industri}

\subsection{Kinerja Pekerja}

Kinerja pekerja merupakan salah satu faktor penting dalam mengembangkan usaha. Indikator kinerja pekerja meliputi kedisiplinan, ketepatan dan ketelitian dalam menyelesaikan tugas, serta produktivitas pekerja. Batasan kedisiplinan yang digunakan adalah disiplin dalam waktu bekerja dan frekuensi kehadiran. Ketelitian dan ketepatan dalam menyelesaikan pekerjaan menunjukkan kemampuan pekerja untuk menghasilkan produk sepatu yang memuaskan dan selesai tepat pada waktunya. Sedangkan produktivitas pekerja dilihat dari produk yang dihasilkan oleh pekerja. Kedisiplinan, ketelitian dan ketepatan, serta produktivitas pekerja sangat dibutuhkan untuk meningkatkan kinerjanya, sehingga semakin tinggi nilai ke empat aspek ini pekerja akan menghasilkan kinerja yang baik.

Kinerja pekerja dalam industri kecil dan menengah memiliki nilai yang berbeda. Perbandingan kinerja dalam industri kecil dan menengah berdasarkan pada aspek indikator kinerja disajikan pada Tabel 3. Dari tabel tersebut menunjukkan bahwa industri menengah memiliki skor rata-rata yang agak lebih tinggi jika dibandingkan dengan skor rata-rata yang diperoleh industri kecil. Industri menengah memiliki skor rata-rata 27 atau 77 persen, sedangkan industri kecil memiliki skor 25.1 atau 71.4 persen. Perbedaan ini terdapat pada semua indikator. Perbedaan terbesar terdapat pada produktivitas pekerja. Skor 
rata-rata produktivitas industri menengah hanya mencapai 68 persen, sedangkan industri menengah mencapai 80 persen (selisih 12 persen).

Tabel 3 Perbandingan kinerja pekerja dalam industri sepatu skala kecil dan menengah

\begin{tabular}{lcccc}
\hline \multirow{2}{*}{$\begin{array}{c}\text { Indikator } \\
\text { Kinerja }\end{array}$} & $\begin{array}{c}\text { Rata- } \\
\text { rata } \\
\text { skor }\end{array}$ & $\begin{array}{c}\text { Industri Kecil } \\
\text { skor dari rata-rata skor } \\
\text { maksimal }\end{array}$ & $\begin{array}{c}\text { Rata2 } \\
\text { skor }\end{array}$ & $\begin{array}{c}\text { Persentase rata-rata } \\
\text { skor dari rata-rata } \\
\text { skor maksimal }\end{array}$ \\
\hline Kedisiplinan & 7 & 70 & 7.3 & 73 \\
\hline $\begin{array}{l}\text { Ketepatan dan } \\
\text { ketelitian }\end{array}$ & 14.7 & 73.5 & 15.7 & 78.5 \\
\hline Produktivitas & 3.4 & 68 & 4 & 80 \\
\hline Semua indikator & 25.1 & 71.4 & 27 & 77 \\
\hline
\end{tabular}

Untuk indikator ketepatan dan ketelitian, antara industri kecil dan industri menengah memiliki perbedaan sebesar 5 persen. Sedangkan untuk kedisiplinan terdapat perbedaan sebesar 3 persen. Perbedaan ini tampak karena adanya perbedaan dalam penanganan pekerja sehubungan dengan kepemimpinan yang dijalankan oleh masing-masing pengusaha.

\section{Hubungan Kinerja Pekerja dan Tingkah Laku Kewiraswastaan Pengusaha Terhadap Perkembangan Usaha dan Produktivitas Industri Kecil dan Menegah}

Berdasarkan pada penilaian pengusaha, dalam waktu lima tahun terakhir ini baik industri kecil maupun industri menengah terus berkembang. Perkembangan usaha yang dilihat dari indikator modal yang digunakan, bahan baku, jumlah produksi, jumlah karyawan, dan keuntungan yang diperoleh dalam waktu lima tahun terakhir terus mengalami peningkatan. Perkembangan usaha pada masing- masing industri dapat dilihat pada Tabel 4. 
Tabel 4 Perkembangan usaha industri menengah selama lima tahun terakhir menurut penilaian pengusaha

\begin{tabular}{lcc}
\hline \multirow{2}{*}{ Indikator } & \multicolumn{2}{c}{ Skor Perkembangan Usaha } \\
\cline { 2 - 3 } & Industri kecil & Industri Menengah \\
\hline Jumlah modal & 3 & 3 \\
\hline Jumlah bahan baku & 3 & 3 \\
\hline Jumlah produksi & 3 & 3 \\
\hline Jumlah karyawan & 2 & 3 \\
\hline Jumlah keuntungan & 3 & 3 \\
\hline Total & 14 & 15 \\
\hline
\end{tabular}

Keterangan:

3: mengalami peningkatan

2: mengalami keadaan yang sama

1: mengalami penurunan

Tabel 4 menunjukkan bahwa industri kecil dan industri menengah dalam waktu lima tahun terakhir secara umum mengalami perkembangan usaha. Skor yang diperoleh industri kecil sebesar 14 (93 persen dari skor maksimal), sedangkan industri menegah 15 (100 persen dari skor maksimal). Peningkatan ini terjadi pada semua indikator, kecuali pada industri kecil dimana indikator jumlah pekerja relatif tidak berubah dibanding waktu lima tahun yang lalu.

Sebagaimana yang dikemukakan sebelumnya bahwa kinerja dan tingkah laku kewiraswastaan berpengaruh terhadap perkembangan usaha. Kinerja pekerja dan tingkah laku kewiraswastaan yang tinggi akan mempengaruhi besar kecilnya produksi. Kinerja pekerja, tingkah laku kewiraswastaan pengusaha dan perkembangan usaha industri sepatu skala kecil dan menengah dapat dilihat pada Tabel 5. 
Tabel 5. Kinerja Pekerja, Tingkah Laku Kewiraswastaan Pengusaha dan Perkembangan Usaha Industri Sepatu Skala Kecil dan Menengah

\begin{tabular}{|c|c|c|}
\hline \multirow{2}{*}{ Aspek } & Industri Kecil & $\begin{array}{l}\text { Industri } \\
\text { Menegah }\end{array}$ \\
\hline & $\begin{array}{l}\text { Angka / } \\
\text { Uraian }\end{array}$ & $\begin{array}{c}\text { Angka / } \\
\text { Uraian }\end{array}$ \\
\hline $\begin{array}{l}\text { Kinerja Pekerja } \\
\text { a. Persen pekerja yang memiliki kinerja tinggi } \\
\text { b. Skor rata-rata kinerja pekerja } \\
\text { c. Persen skor rata-rata kinerja pekerja dari skor } \\
\text { maksimal } \\
\text { d. Skor produktivitas } \\
\text { e. Persen skor produtivitas dari skor maksimal }\end{array}$ & $\begin{array}{l}45.45 \% \\
25.1 \\
71.4 \% \\
3.4 \\
68 \%\end{array}$ & $\begin{array}{l}60 \% \\
27 \\
77 \% \\
4 \\
80 \%\end{array}$ \\
\hline $\begin{array}{l}\text { Tingkah Laku Kewiraswastaan } \\
\text { a. Skor pada tingkat pemikiran } \\
\text { b. Persen skor pada tingkat pemikiran dari skor } \\
\text { maksimal } \\
\text { c. Skor pada tingkat tindakan } \\
\text { d. Persen skor pada tingkat tindakan dari skor } \\
\text { maksimal }\end{array}$ & $\begin{array}{c}48 \\
80 \% \\
38 \\
63.3 \%\end{array}$ & $\begin{array}{c}57 \\
95 \% \\
54 \\
90 \%\end{array}$ \\
\hline $\begin{array}{l}\text { Perkembangan Usaha } \\
\text { a. Indikator perkembangan usaha yang tidak } \\
\text { meningkat } \\
\text { b. Skor perkembangan usaha } \\
\text { c. Persen skor perkembangan usaha dari skor } \\
\text { maksimal }\end{array}$ & $\begin{array}{c}\text { Jumlah } \\
\text { pekerja } \\
14 \\
93 \%\end{array}$ & $\begin{array}{c}- \\
15 \\
100 \%\end{array}$ \\
\hline
\end{tabular}

Dari gambaran kedua industri sepatu yang telah disajikan, tampak bahwa baik industri kecil maupun industri menengah mengalami perkembangan usaha, tetapi perkembangan usaha yang terjadi pada kedua industri berbeda. Industri menengah mengalami perkembangan usaha yang lebih cepat dibandingkan dengan industri kecil. Dari waktu yang cukup lama (awal berdiri hingga saat sekarang), industri kecil tetap berada dalam kategori industri kecil, sedangkan industri sepatu menengah, pada mulanya tergolong usaha industri kecil, dengan perkembangan usaha yang relatif cepat kemudian berkembang menjadi usaha industri menengah.

Dari paparan sebelumnya dapat dinyatakan bahwa perkembangan usaha yang berbeda itu terutama adalah sebagai akibat atau berhubungan erat dengan kepemimpinan dan tingkah laku kewiraswastaan yang ada pada masing-masing usaha industri tersebut. Kepemimpinan mempengaruhi kinerja pekerja. Telah terbukti bahwa kinerja pekerja berhubungan nyata dengan kepemimpinan yang dialami berdasarkan penilaian pekerja yang bersangkutan. Semakin tinggi skor kepemimpinan berdasarkan penilaian pekerja, maka semakin tinggi pula skor kinerja pekerja yang bersangkutan. Kinerja pekerja pada industri menengah lebih tinggi dari kinerja pekerja pada industri kecil. 
Tingkat tingkah laku kewiraswastaan dan kemampuan mewujudkan tingkah laku kewiraswastaan yang ada pada tingkat pemikiran ke dalam bentuk tindakan sangat menentukan perkembangan usaha yang terjadi. Ternyata, selain tingkah laku kewiraswastaan pada tingkat pemikiran yang dimiliki pengusaha industri menengah lebih tinggi, juga kemampuan pengusaha industri menengah untuk mewujudkannya ke tingkat tindakan lebih besar dibandingkan dengan pengusaha industri kecil.

\section{Kesimpulan dan Saran}

\section{1. Kesimpulan}

1. Kedua pengusaha mempunyai kemampuan menjalankan kepemimpinan yang efektif di kalangan pekerja. Kepemimpinan yang dijalankan oleh kedua pengusaha tidak terlepas dari pengalaman kepemimpinan yang pernah mereka lakukan dan juga dari proses sosialisasi baik dari lingkungan internal yaitu yang mereka terima dari orang tua, maupun dari lingkungan eksternal yaitu lingkungan masyarakat dimana mereka tinggal.

2. Kedua pengusaha mempunyai kemampuan menjalankan kepemimpinan yang efektif di kalangan pekerja. Meskipun demikian masih terdapat perbedaan antara kedua pengusaha. Perbedaan yang terlihat adalah mengenai penanganan terhadap kesalahan pekerja dan penerapan gaya kepemimpinan dalam perilaku dasar pengambilan keputusan. Gaya kepemimpinan yang diterapkan dalam industri sepatu skala kecil adalah gaya instruktif dan gaya konsultatif, sedangkan gaya kepemimpinan yang diterapkan dalam industri menengah hanya gaya instruktif.

3. Tingkat kinerja pekerja pada kedua industri tergolong cukup tinggi, namun lebih tinggi pada industri menengah. Pada kedua industri terdapat hubungan yang nyata antara kinerja pekerja dan kepemimpinan.

4. Tingkat tingkah laku kewiraswastaan pengusaha industri menengah tergolong lebih tinggi dibandingkan dengan pengusaha industri kecil baik pada tingkat pemikiran maupun pada tingkat tindakan. Tingkat tingkah laku kewiraswastaan pengusaha industri menengah lebih tinggi dari pada pengusaha industri kecil pada semua unsur tingkah laku kewiraswastaan. Hal ini menunjukkan pengusaha industri menengah lebih mampu mewujudkan pemikiran-pemikirannya dalam bentuk tindakan nyata dibandingkan dengan pengusaha industri kecil.

5. Terdapat hubungan antara kinerja pekerja dan tingkah laku kewiraswastaan terhadap perkembangan usaha industri yang bersangkutan. Dengan tingkat kinerja pekerja dan tingkah laku kewiraswastaan pengusaha yang lebih tinggi (pada tingkat pemikiran dan tingkat tindakan), usaha industri menengah mengalami perkembangan usaha yang lebih cepat dan mempunyai produktivitas yang lebih tinggi dibandingkan dengan usaha industri kecil. Industri menengah, semula tergolong indutri kecil dan berkembang menjadi industri menengah dalam waktu yang relatif pendek, sementara industri kecil tidak berubah statusnya. Keadaan ini berhubungan 
erat dengan kemampuan pengusaha industri menengah yang lebih besar dari pengusaha industri kecil untuk mewujudkan tingkah laku kewiraswastaan yang ada pada tingkat pemikiran ke tingkat tindakan atau senyatanya serta tingkat kinerja pekerja yang lebih tinggi pada industri menengah di bawah kepemimpinan yang bersangkutan.

\subsection{Saran}

Berdasarkan hasil penelitian ini, untuk lebih mengembangkan industri kecil dan menengah perlu didukung upaya-upaya yang tertuju kepada pembentukan kepemimpinan pengusaha industri yang mampu meningkatkan kinerja pekerja. Dukungan lain yang diperlukan adalah upaya untuk mengembangkan pola tingkah laku kewiraswastaan bagi pengusaha-pengusaha industri kecil dan menengah serta meningkatkan kemampuannya dalam mewujudkan tingkah laki kewiraswastaan yang ada pada tingkat pemikiran menjadi tindakan nyata. Selain itu yang disarankan untuk dilakukan penelitian-penelitian lanjutan guna mengkaji dan menggali informasi lebih dalam mengenai kepemimpinan dan tingkah laku kewiraswastaan pengusaha dalam hubungannnya dengan perkembangan dan produktivitas usaha industri pada industri-industri yang lain.

\section{Daftar Pustaka}

Aziz, M Amin. 1978. Tingkah Laku kewiraswastaan di Kalangan Petani Aceh. Prisma 9, Edisi September. LP3ES. Jakarta.

BPS. 2000. Statistik Indonesia 2000. Badan Pusat Statistik. Jakarta. Indonesia.

Gerschenkron, A. 1996. The Modernization of Enterpreneurship dalam M Weiner (ed) Modernization: The Dynamic of Growth. Voice of America Forum Lecturer. Cambridge.

Kartodirdjo, Sartono. 1984. Kata Pengantar dalam Sartono Kartodirdjo (Penyunting): Kepemimpinan dalam Simensi Sosial. LP3ES. Jakarta.

Kottler, Jhon. 1996. The Leadership Factor. Prehalindo. Jakarta

Nawawi, Hadari. 2003. Kepemimpinan Mengefektifkan Organisasi. Gadjah Mada University Press. Yogyakarta.

Novrizar, A. 2002. Analisis Kepuasan Kerja dalam Upaya meningkatkan Kinerja Pegawai Negeri Sipil Pemerintah Provinsi Daerah Khusus Ibukota Jakarta. Tesis. MMA-IPB. Bogor.

Soekanto, Soerjono. 1990. Sosiologi Suatu pengantar. PT. Raja Grafindo Persada. Jakarta. 